\title{
Chiral trans-1,2-diaminocyclohexane derivatives as chiral solvating agents for carboxylic acids
}

\author{
MARIAPPAN PERIASAMY*, MANASI DALAI and MEDURI PADMAJA \\ School of Chemistry, University of Hyderabad, Central University P.O., Hyderabad 500046 \\ e-mail: mpsc@uohyd.ernet.in
}

MS received 27 August 2009; revised 20 May 2010; accepted 16 June 2010

\begin{abstract}
Efficient use of the readily accessible chiral $C_{2}$-symmetric acyclic diamines (1-2) as well as macrocyclic amines (3-5) containing trans-1,2-diaminocyclohexyl moiety as chiral solvating agents (CSA) for the determination of enantiomeric excess of representative carboxylic acids (6-7) and an amino acid derivative (8) is illustrated. The enantiomeric composition of different carboxylic acids estimated here by the ${ }^{1} \mathrm{H}$ NMR method, based on the integration of the corresponding methine proton signals are in good correlation with that determined using HPLC method. The data are in accordance with the formation of multimolecular diastereomeric complexes in solution, which render good splitting of NMR signals for the enantiomers of representative carboxylic acids as well as for $N$-Ts-phenylglycine (up to $\Delta \Delta \delta=0.295 \mathrm{ppm}, 118 \mathrm{~Hz}$ ).
\end{abstract}

Keywords. Chiral 1,2-cyclohexyl diamines; macrocyclic amines; chiral solvating agents; enantiomeric purity; chiral carboxylic acids.

\section{Introduction}

In view of the importance of chiral organic compounds in biological and pharmaceutical chemistry, ${ }^{1-4}$ there is increasing requirement for fast and accurate methodologies for the determination of enantiomeric composition of these chiral compounds. Among the various available methods, NMR spectroscopy has the advantages of easy performance and accessibility $^{5}$ with no need for special equipment apart from the common NMR spectrometers. As enantiomers cannot be distinguished in an achiral environment, these techniques require the modification of the substrate with a chiral auxiliary, which would convert the mixture of enantiomers into a mixture of diastereomeric molecular (covalent, chiral derivatizing agent, CDA) or supramolecular (non-covalent, chiral solvating agents, CSA) complexes. ${ }^{6}$ Ideally, these diastereomeric species will show chemical shift nonequivalence of some of their NMR signals, allowing the determination of the enantiomeric composition of the substrate by the direct integration of these bands. ${ }^{7}$ The advantage of using non-covalent chiral solvating agents relies on the possibility of carrying out the experiment in situ, without purification

*For correspondence steps. ${ }^{8}$ Besides the starting chiral materials, analytes and the CSA could be easily recovered after the measurement. The wide variety of chiral shift reagents, such as lanthanide complexes, ${ }^{9}$ crown ether, ${ }^{10}$ cyclodextrin, ${ }^{11}$ porphyrins, ${ }^{12}$ macrocycles, ${ }^{13}$ and others ${ }^{14}$ have already been reported. However, there are only few reports on the development of efficient chiral shift reagents for carboxylic acids, in spite of their importance in chemistry. ${ }^{15}$

Chiral macrocyclic compounds have been recognized as successful and promising chiral selectors for molecular recognition, mainly because of their inherent reduced flexibility and complexation ability. ${ }^{16}$ Recently, Tanaka et $a l^{17}$ reported that chiral macrocyclic amine functions as highly sensitive chiral shift reagent for several kinds of secondary alcohols, cyanohydrins and propargyl alcohols. However, these macrocycles are not useful as chiral shift reagents for carboxylic acids, without introduction of both hydrogen bond acceptor and donor group in the host macrocycles for multiple binding with the carboxylic acids. ${ }^{18}$ Accordingly, in continuation of our research efforts towards the synthesis of chiral macrocycles ${ }^{19}$ and other chiral $N$-alkylated amines ${ }^{20}$ containing trans-1,2-diaminocyclohexane moiety (figure 1), we have examined their use as chiral solvating agents for the determi- 


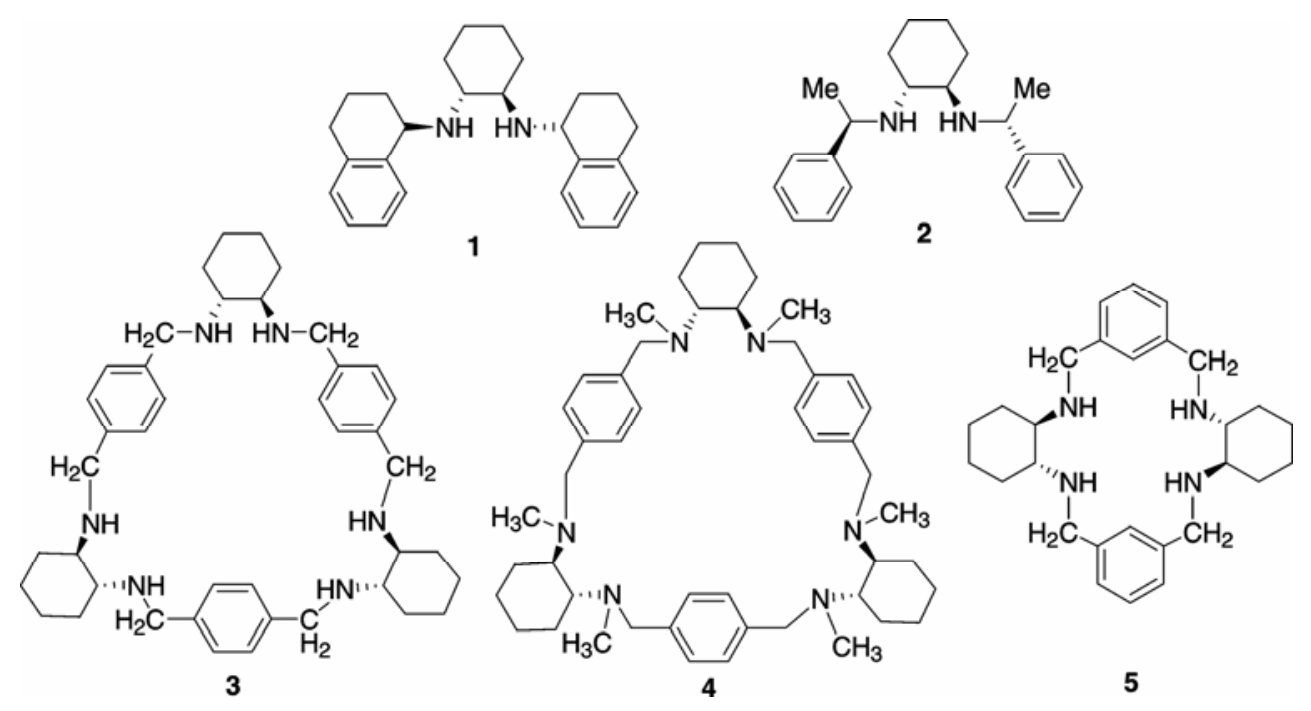

Figure 1. Structures of the receptors studied 1-5.

nation of enantiomeric excess of carboxylic acids by ${ }^{1} \mathrm{H}$ NMR spectroscopy. The results are presented here.

\section{Experimental}

\subsection{Materials, method and instruments}

Infrared spectra were recorded on JASCO FT-IR spectrophotometer Model 5300. ${ }^{1} \mathrm{H}$ NMR and ${ }^{13} \mathrm{C}$ NMR spectra were recorded on Bruker AV-400 spectrometer with chloroform- $d$ as a solvent and TMS as the reference ( $\delta=0 \mathrm{ppm})$. Coupling constants $J$ reported are in $\mathrm{Hz}$. Elemental analyses were carried out on a Flash EA 1112 series analyzer. Optical rotations were measured in an AUTOPOL-IV automatic polarimeter (readability \pm 0.001 ). Chromatography was carried out using Acme's silica gel (100200 mesh and 230-400 mesh). The commercial cis/trans mixture of 1,2-diaminocyclohexane was resolved following a reported procedure. ${ }^{27}$ Isophthaloyl chloride was prepared from isophthalic acid and distilled under reduced pressure. The racemic 2,3-diphenylsuccinic acid was synthesized following a reported procedure. ${ }^{28}$

\subsection{Procedure for the synthesis of chiral macrocyclic amine (4)}

The secondary macrocyclic amine $3(2.4 \mathrm{mmol}$, $1.5 \mathrm{~g})$, formic acid $(2 \mathrm{~mL})$ and formaldehyde $(1 \mathrm{~mL})$ were heated at $110^{\circ} \mathrm{C}$ for $12 \mathrm{~h}$. The reaction mixture was neutralized with $2 \mathrm{~N} \mathrm{NaOH}(15 \mathrm{~mL})$ and extracted with dichloromethane $(2 \times 15 \mathrm{~mL})$. The combined organic extracts were washed with brine $(15 \mathrm{~mL})$, dried over anhydrous sodium sulphate and evaporated to give the permethylated product 4.

Yield: $1.58 \mathrm{~g}(90 \%) ;$ m.p.: $178-180^{\circ} \mathrm{C}$; $[\alpha]_{\mathrm{D}}^{25}=-$ 16.9 (c 0.9, $\mathrm{CH}_{2} \mathrm{Cl}_{2}$ ); IR (KBr): 3028, 2926, 1450, $763 \mathrm{~cm}^{-1} ;{ }^{1} \mathrm{H}-\mathrm{NMR}\left(400 \mathrm{MHz}, \mathrm{CDCl}_{3}\right) \delta 1 \cdot 15-1.23$ $(m, 6 \mathrm{H}), 1.30-1.40(m, 6 \mathrm{H}), 1.80-1.85(m, 6 \mathrm{H})$, $2 \cdot 00-2.05(m, 6 \mathrm{H}), 2 \cdot 21(\mathrm{~s}, 18 \mathrm{H}), 2 \cdot 72-2.74(\mathrm{~m}$, $6 \mathrm{H}), 3.76(q, J=12.8 \mathrm{~Hz}, 12 \mathrm{H}), 7.40(s, 12 \mathrm{H})$; ${ }^{13} \mathrm{C}-\mathrm{NMR}\left(50 \mathrm{MHz}, \mathrm{CDCl}_{3}\right) \delta 25 \cdot 9,26 \cdot 3,35 \cdot 8,58 \cdot 6$, 64.9, 128.6, 139.3; CHN calculated: C, 78.5\%; H, $9.8 \% ; \mathrm{N}, 11.4 \%$; Found: C, $78.5 \% ; \mathrm{H}, 9.9 \% ; \mathrm{N}$, $11.4 \%$; MS (LCMS): $\mathrm{C}_{48} \mathrm{H}_{72} \mathrm{~N}_{6}(m / z 734 \mathrm{M}+1)$.

\subsection{Procedure for the synthesis of the chiral mac- rocyclic amine (5)}

To a stirred solution of $(R, R)$-1,2-diaminocyclohexane $(10 \mathrm{mmol}, 1.14 \mathrm{~g})$ and triethylamine $(5.6 \mathrm{~mL})$ in dichloromethane $(40 \mathrm{~mL})$, isophthaloyl chloride $(10 \mathrm{mmol}, 2 \mathrm{~g})$ was added at $0^{\circ} \mathrm{C}$ and the reaction mixture was allowed to stir at $25^{\circ} \mathrm{C}$ for $12 \mathrm{~h}$. The reaction was quenched with water $(15 \mathrm{~mL})$. The residues were filtered off and washed with dichloromethane $(20 \mathrm{~mL})$ to obtain the insoluble polyamide. To a suspension of $\mathrm{NaBH}_{4}$ $(40 \mathrm{mmol}, 1.43 \mathrm{~g})$ in tetrahydrofuran $(150 \mathrm{~mL})$, a solution of $I_{2}(20 \mathrm{mmol}, 4.8 \mathrm{~g})$ in THF $(30 \mathrm{~mL})$ was added at $0^{\circ} \mathrm{C}$ under nitrogen atmosphere over $30 \mathrm{~min}$. The polyamide ( $1 \mathrm{~g})$ was added to the gen- 
erated diborane and refluxed for $24 \mathrm{~h}$. The reaction was quenched with methanol and the solvents were evaporated. The residue obtained after evaporation was refluxed with $10 \mathrm{~N} \mathrm{KOH}$ for $6 \mathrm{~h}$ and the resultant polyamine was extracted with dichloromethane $(2 \times 30 \mathrm{~mL})$. The organic extracts were washed with brine $(30 \mathrm{~mL})$, dried over anhydrous sodium sulphate and the residue was evaporated to obtain the polyamine. The crude amine was chromatographed on a silica gel column using chloroform:methanol $(95: 5)$ to obtain the macrocyclic amine 5 in pure form

Yield: $0.2 \mathrm{~g}(23 \%) ;$ m.p.: $108-110^{\circ} \mathrm{C} ;[\alpha]_{\mathrm{D}}^{25}=$ -101 (c 0.4, $\mathrm{CHCl}_{3}$ ); IR (KBr) 3296, 3024, 2928, 1452, $1114,787 \mathrm{~cm}^{-1} ;{ }^{1} \mathrm{H}-\mathrm{NMR}\left(400 \mathrm{MHz}, \mathrm{CDCl}_{3}\right)$ $\delta 1.056(m, 4 \mathrm{H}), 1.28(m, 4 \mathrm{H}), 1.79(m, 9 \mathrm{H}), 2.28$ $(m, 7 \mathrm{H}), 3.66(d, J=12.8 \mathrm{~Hz}, 4 \mathrm{H}), 3.96 \quad(d$, $J=13.2 \mathrm{~Hz}, 4 \mathrm{H}), \quad 7.07(d, J=7.6 \mathrm{~Hz}, 4 \mathrm{H}), 7.20$ $(m, 2 \mathrm{H}), 7.64(s, 2 \mathrm{H}) ;{ }^{13} \mathrm{C}$-NMR $\left(50 \mathrm{MHz}, \mathrm{CDCl}_{3}\right) \delta$ $25 \cdot 1,31 \cdot 4,50 \cdot 8,60 \cdot 9,126 \cdot 4,126 \cdot 9,127 \cdot 7,141 \cdot 1$; CHN calculated: $\mathrm{C}, 77.7 \% ; \mathrm{H}, 9.2 \% ; \mathrm{N}, 12.9 \%$; found: $\mathrm{C}, 77.7 \% ; \mathrm{H}, 9.3 \%$; N, 12.8\%; MS (LCMS): $\mathrm{C}_{28} \mathrm{H}_{40} \mathrm{~N}_{4}(m / z 433(\mathrm{M}+1)$

\section{$2.4{ }^{1} H$-NMR shift experiments}

NMR shift experiments were performed on a $400 \mathrm{MHz}$ NMR spectrometer at $25^{\circ} \mathrm{C}$ by mixing the compounds 1-5 with the acids 6-8 in varying ratios in $\mathrm{CDCl}_{3}$, until maximum splitting of the signals were observed.

2.4a Evaluation of stoichiometry of the complex formed between 1 and (R)-and (S)-mandelic acid $\mathbf{6}$ by Job's method: The stoichiometry of the complex formed between $\mathbf{1}$ and $\mathbf{6}$ was determined according to Job's method of continuous variations. Equimolar amounts of $1(0.025 \mathrm{M})$ and $(R)$ or $(S)-6$ $(0.025 \mathrm{M})$ were prepared in $\mathrm{CDCl}_{3}(5 \mathrm{~mL})$. These solutions were distributed among ten NMR tubes in such a way that the mole fractions of $\mathbf{1}$ and $\mathbf{6}$ in the resulting solutions increased from $0 \cdot 1$ to 0.9 . The complexation induced shifts of the methine signal $(\Delta \delta)$ were multiplied by the mole fraction of the acid $6(\mathrm{X})$ and plotted against X to obtain the Job's plot (figure 2).

$2.4 \mathrm{~b}$ Evaluation of the stoichiometry of the complex formed between 3 and $(R)$-and (S)-mandelic acid $\mathbf{6}$ by Job's method: The stoichiometry of the complex formed between $\mathbf{3}$ and $\mathbf{6}$ was determined according to the Job's method of continuous variations. Equimolar amounts of $3(0.0025 \mathrm{M})$ and $(R)$ or $(S)-6(0.0025 \mathrm{M})$ were prepared in $\mathrm{CDCl}_{3}(5 \mathrm{~mL})$. These solutions were distributed among ten NMR tubes in such a way that the mole fractions of $\mathbf{3}$ and 6 in the resulting solutions increased from $0 \cdot 1$ to $0 \cdot 9$. The complexation induced shifts of the methine signal $(\Delta \delta)$ were multiplied by the mole fraction of the acid $6(\mathrm{X})$ and plotted against X to obtain the Job's plot (figure 3).

2.4c ${ }^{1} H$-NMR titrations: The mandelic acid 6 $[(R)$ or $(S)](0.0031 \mathrm{M}[2.4 \mathrm{mg}$ in $5 \mathrm{~mL}])$ was dissolved in $\mathrm{CDCl}_{3}$ and evenly distributed $(0.5 \mathrm{~mL})$ among ten NMR tubes. The first NMR tube was sealed without any amine. The macrocyclic amine $\mathbf{3}$ was dissolved in $\mathrm{CDCl}_{3} \quad(0.039 \mathrm{M}[51.5 \mathrm{mg}$ in $2 \mathrm{~mL}]$ ) and added in increasing amounts to the NMR tubes so that the solutions with relative concentrations of the amine versus acid of $0.25,0.5,0.75$, $1.00,1.25,1.50,2.00,2.50$ and 3.00 are obtained. The change in the chemical shift values of the methine signal is plotted against the relative concentration of the acid versus amine in a $400 \mathrm{MHz}$ NMR spectrometer.

\section{Results and discussion}

We have chosen the chiral diamines (1-2) and macrocyclic amines (3-5) to examine their chiral recog-

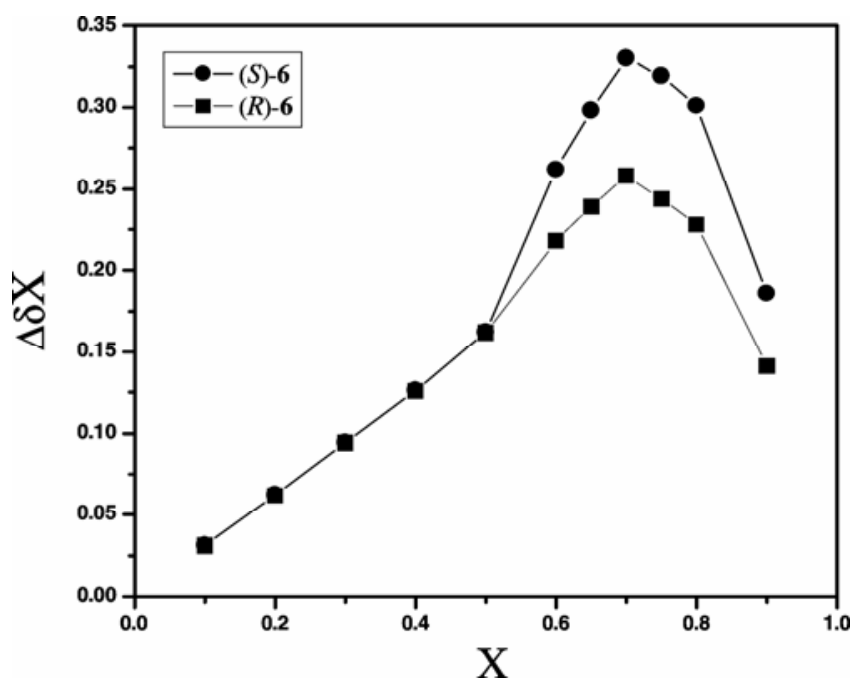

Figure 2. Job's plot obtained for 1 and either $(R)$ and $(S)$-mandelic acids $6[\mathrm{X}=$ mole fraction of the acid; $\Delta \delta=$ change in the chemical shift of the $\mathrm{C}^{\alpha} \mathrm{H}$ proton signal of $(R)$ - and $(S)$-mandelic acid]. 
nition ability towards mandelic acid 6 and 2,3diphenylsuccinic acid 7 and $N$-Ts-phenylglycine 8 by ${ }^{1}$ H-NMR spectroscopy. The chiral diamines $\mathbf{1}$ and 2 were readily synthesized by reductive $N$ alkylation of $(R, R)$-trans-1,2-diaminocyclohexane with corresponding prochiral ketones in this laboratory $^{20}(1)$.

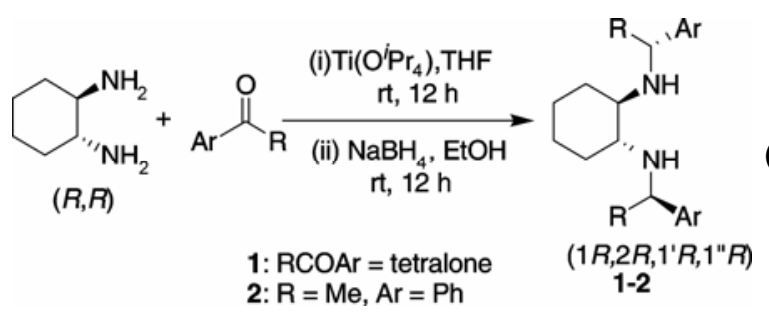

The macrocycle 3 was synthesized following a reported procedure ${ }^{21}$ via $[3+3]$ cyclocondensation of $(R, R)$-1,2-diaminocyclohexane with terephthalaldehyde and then reduction of the corresponding macrocyclic hexaimine using $\mathrm{NaBH}_{4} / \mathrm{MeOH}$ reagent system (2)

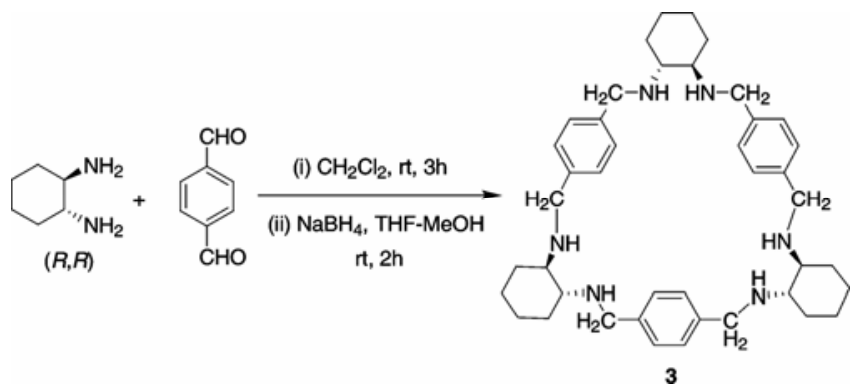

(2)

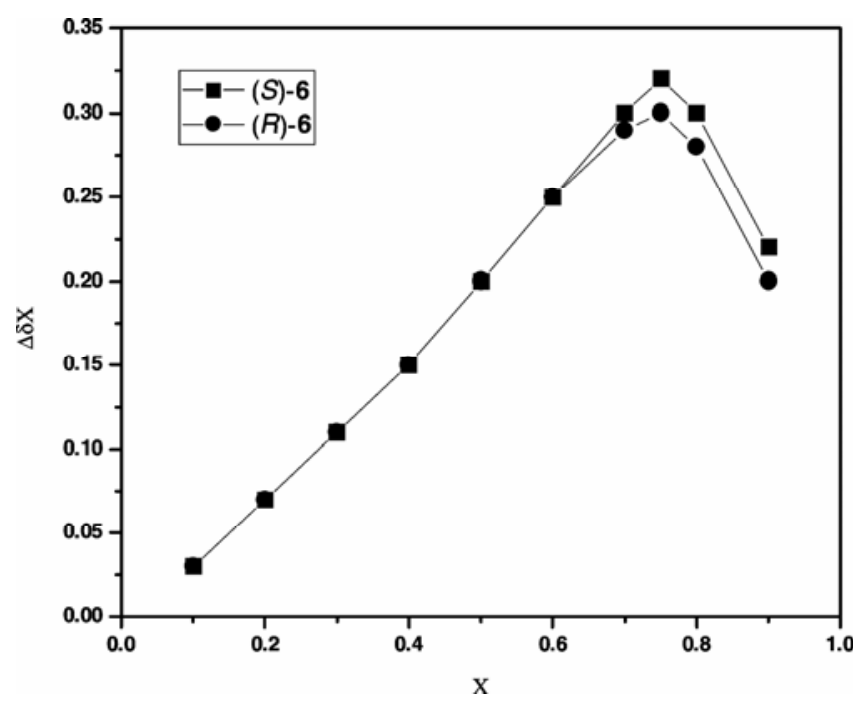

Figure 3. Job's plot obtained for 3 and either $(R)$ - and $(S)$-mandelic acids $6[X=$ mole fraction of the acid; $\Delta \delta=$ change in the chemical shift of the $\mathrm{C}^{\alpha} \mathrm{H}$ proton signal of $(R)$ - and $(S)$-mandelic acid].
The macrocycle 4 was prepared by the methylation of $3^{22}$ using a mixture of formic acid and formaldehyde (3).

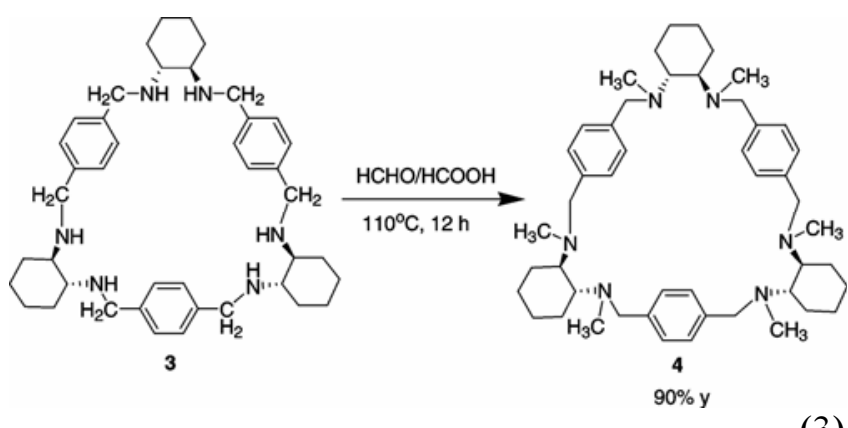

The macrocycle $\mathbf{5}$ was synthesized by $\mathrm{NaBH}_{4} / \mathrm{I}_{2}{ }^{23}$ reduction of insoluble mixture of the amides obtained by the reaction of $(R, R)$-1,2-diaminocyclohexane with isophthaloyl chloride (4). ${ }^{24}$ The mixture of the amines obtained after reduction was purified by chromatography to obtain the macrocyclic amine 5 in pure form.

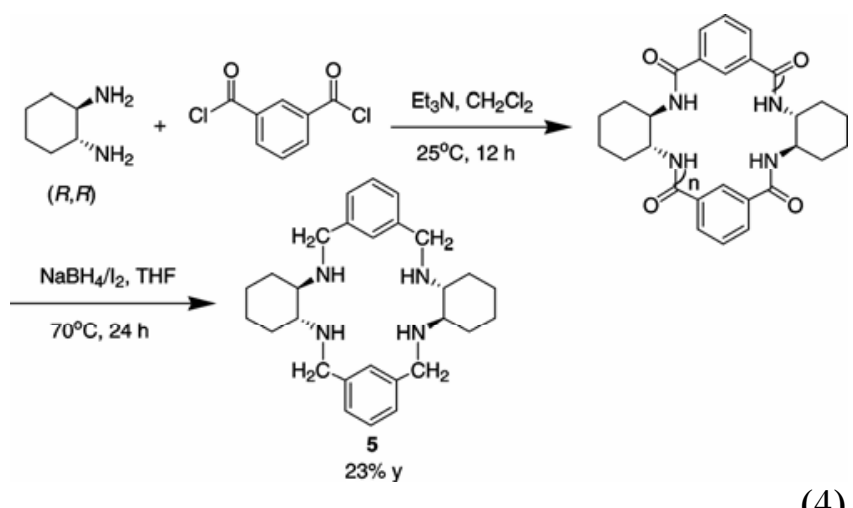

The presence of the protonable amine groups ${ }^{25}$ would lead to the formation of corresponding diastereomeric salt with chiral carboxylic acids. As a result, the methine proton signal of the carboxylic acids splits into two singlets. Initially, the easily accessed chiral amines $\mathbf{1}$ and $\mathbf{2}$ were examined as chiral sol-

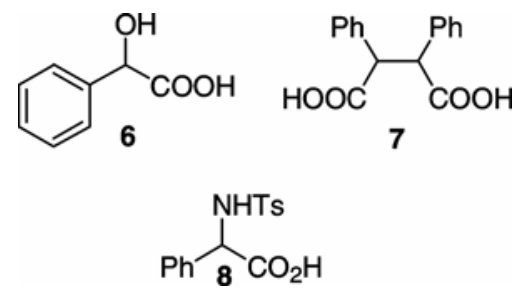

Figure 4. Structures of the carboxylic acids (6-8) studied. 
Table 1. Measurement of ${ }^{1} \mathrm{H}$ chemical shift non-equivalences $(\Delta \Delta \delta)$ of the acids 6-8 in the presence of chiral acyclic amine receptor 1-2 by ${ }^{1} \mathrm{H}$ NMR spectroscopy (400 MHz,) in $\mathrm{CDCl}_{3}{ }^{\mathrm{a}}$.

\begin{tabular}{|c|c|c|c|c|c|}
\hline \multirow[b]{2}{*}{ Acid } & \multirow[b]{2}{*}{ Proton } & \multicolumn{2}{|c|}{ Amine-1 } & \multicolumn{2}{|c|}{ Amine-2 } \\
\hline & & Ratio of amine : acid & $\Delta \Delta \delta(\mathrm{Hz})$ & Ratio of amine : acid & $\Delta \Delta \delta(\mathrm{Hz})$ \\
\hline & $\alpha-\mathrm{H}$ & $1: 3$ & $53 \cdot 6$ & $1: 2 \cdot 3$ & 48 \\
\hline & $\alpha-\mathrm{H}$ & $1: 1$ & 69 & $1: 2$ & $55 \cdot 2$ \\
\hline & $\alpha-\mathrm{H}$ & & 118 & & $28 \cdot 6$ \\
\hline & $\mathrm{CH}_{3}(\mathrm{Ts})$ & $1: 3$ & $3 \cdot 2$ & $1: 3$ & $2 \cdot 9$ \\
\hline & $\mathrm{NH}$ & & $68 \cdot 7$ & & $0 \cdot 0$ \\
\hline
\end{tabular}

${ }^{a}$ Typical conditions: concentration of the acid and the receptor is $100 \mathrm{mM}$ in $0.5 \mathrm{~mL}$ of $\mathrm{CDCl}_{3}$, and the spectra are recorded at $25^{\circ} \mathrm{C}$.

(a)
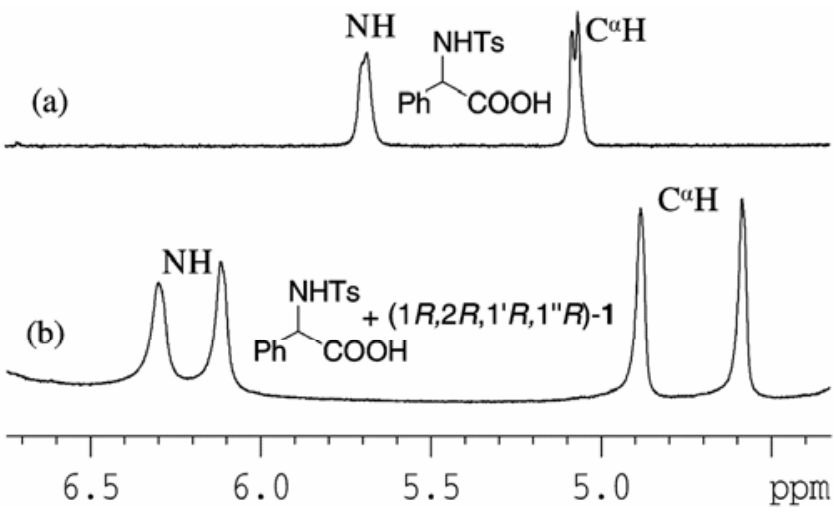

Figure 5. Partial ${ }^{1} \mathrm{H}$ NMR spectra showing $\mathrm{C}^{\alpha} \mathrm{H}$ and $\mathrm{NH}$ signals for racemic $8\left(100 \mathrm{mM}, \mathrm{CDCl}_{3}, 400 \mathrm{MHz}\right.$, $\left.25^{\circ} \mathrm{C}\right)$ (a) in the absence and (b) in the presence of 0.33 equiv. of $(R, R, R, R)-\mathbf{1}$.

vating agents towards mandelic acid $\mathbf{6}$, and 2,3diphenylsuccinic acid 7 and $N$-Ts-phenylglycine 8 by ${ }^{1} \mathrm{H}-\mathrm{NMR}$ spectroscopy (figure 4 ).

The experiments were carried out by adding increasing amounts of solution of racemic acid (6-8) in $\mathrm{CDCl}_{3}(100 \mathrm{mM})$ to a solution of chiral amine (12) in $\mathrm{CDCl}_{3}(100 \mathrm{mM})$. Immediately after each addition, ${ }^{1} \mathrm{H}$ NMR spectrum was acquired in a $400 \mathrm{MHz}$ spectrometer at room temperature. The splitting values between proton signals corresponding to each enantiomer of acids (6-8) $(\Delta \Delta \delta)$ after addition of receptors (1-2) are summarized in table 1 . In the presence of receptors 1 and/or 2 , the chemical shift nonequivalences of at least one of the protons of selected acids are large enough to give base line resolution on a $400 \mathrm{MHz}$ NMR instrument at $25^{\circ} \mathrm{C}$. When the receptor 1 to $\mathrm{N}$-Ts-phenylglycine 8 ratio was $1: 3$, maximum non-equivalences of the $\mathrm{C}^{\alpha} \mathrm{H}$ proton $(118 \mathrm{~Hz})$ was obtained (figure 5).
Table 2. Concentration variation of ${ }^{1} \mathrm{H}$ NMR chemical shift non-equvalence $(\Delta \Delta \delta)$ of acid 6 in the presence of receptor amine 1 with the mole ratio of $3: 1$.

\begin{tabular}{lcc}
\hline Entry & Total molar conc. $(\mathrm{mM})$ & $\Delta \Delta \delta(\mathrm{Hz})$ \\
\hline 1 & 0.0025 & 18 \\
2 & 5 & $20 \cdot 4$ \\
3 & 15 & $37 \cdot 6$ \\
4 & 25 & $41 \cdot 2$ \\
5 & 100 & $53 \cdot 6$ \\
\hline
\end{tabular}

Some interesting observations have been made during these studies. First of all, the signals from the acids move upfield $(\Delta \delta<0)$, suggesting a deprotonation of carboxylic group. Only, the $\mathrm{NH}$ proton from $N$-Ts-phenylglycine (8) resonates at lower field upon the addition of receptor, which can be interpreted as formation of a stronger intramolecular hydrogen bond with the carboxylate anion thus formed. Concomitantly, signals from the receptor move downfield, which clearly indicates the proton transfer from the acid to the receptor, leading to the corresponding diastereomeric salts. These salts are expected to form intimate ionic pairs in $\mathrm{CDCl}_{3}$, rendering the observed anisochronic nuclei in NMR for the corresponding enantiomers of acids.

According to the theory of chemical equilibrium, upon increasing the concentration, the mole fraction of the reactants decreases for a combination reaction. So, it can be predicted that when the fractional population of free acid is smaller the $\Delta \Delta \delta$ is larger at a larger concentration, which is in accordance with the experiments (table 2) on the effect of concentration on the ${ }^{1} \mathrm{H}$ chemical shift non-equivalences $(\Delta \Delta \delta)$ of the strong acid 6 in the presence of recep- 
tor 1. When the concentration decreased from $100 \mathrm{mM}$ to $0.0025 \mathrm{mM}$, the non-equivalent chemical shift is decreased by only $35.6 \mathrm{~Hz}$, from $53.6 \mathrm{~Hz}$ to $18 \mathrm{~Hz}$

To confirm the formation of multimolecular complexes, Job's plot analysis was performed for each enantiomer of the acid 6 (figure 2) in separate experiments, showing a clear $1: 3$ receptor:acid stoichiometry for both enantiomers of the acid with receptor 1 as expected from the experimental data.

Finally, we have examined the practical applicability of this method for the measurement of enantiomeric excess of carboxylic acids. With this aim, samples containing different proportions of both the enantiomers of $6\left(100 \mathrm{mM}\right.$ in $\left.5 \mathrm{~mL} \mathrm{CDCl}_{3}\right)$ were prepared and analysed with ${ }^{1} \mathrm{H}$ NMR method using the receptor amine $1\left(100 \mathrm{mM}\right.$ in $\left.5 \mathrm{~mL} \mathrm{CDCl}_{3}\right)$ in $1: 3$ receptor : acid molar ratio (figure 7). Integration of the corresponding $\mathrm{C}^{\alpha} \mathrm{H}{ }^{1} \mathrm{H}$ NMR signals show an excellent linear correlation of the observed $\%$ ee's with that of expected \% ee's based on HPLC method. ${ }^{29}$

Similarly, we have examined the chiral recognition ability of easily accessed chiral macrocyclic amines (3-5) towards mandelic acid 6 and 2,3diphenylsuccinic acid 7 by ${ }^{1} \mathrm{H}$ NMR spectroscopy. The experiments were carried out by adding increasing amounts of the solution of racemic mandelic acid 6 in $\mathrm{CDCl}_{3}(30 \mathrm{mM})$ to a solution of the chiral macrocyclic amine (3-5) in $\mathrm{CDCl}_{3}(30 \mathrm{mM})$. Immediately after each addition, ${ }^{1} \mathrm{H}$ NMR spectrum was recorded in a $400 \mathrm{MHz}$ spectrometer at $25^{\circ} \mathrm{C}$. Different receptors (3-5) to acid 6 molar ratios were analysed.

Similar experiments were carried out by varying the amounts of solution of the chiral macrocyclic

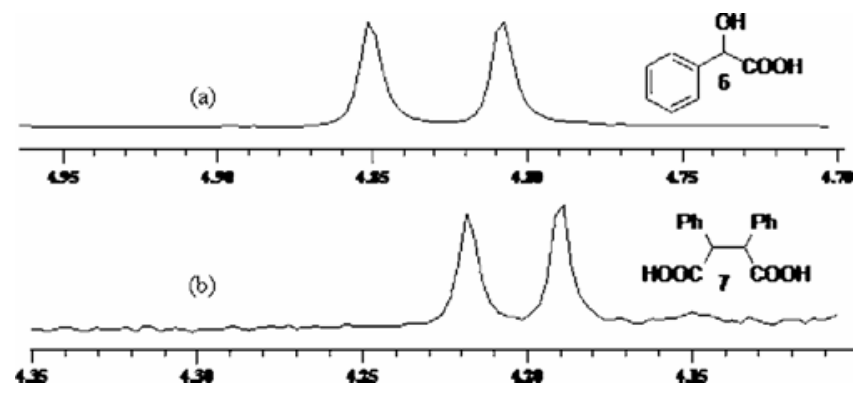

Figure 6. Partial ${ }^{1} \mathrm{H}$ NMR spectra showing $\mathrm{C}^{\alpha} \mathrm{H}$ signal for racemic acids 6 and $7\left(30 \mathrm{mM}, \mathrm{CDCl}_{3}, 400 \mathrm{MHz}\right.$, $25^{\circ} \mathrm{C}$ ) (a) in the presence of macrocyclic amine $3\left(0.33\right.$ equiv. of $\left.30 \mathrm{mM}, \mathrm{CDCl}_{3}\right)$ (b) in the presence of macrocyclic amine 3 (6 equiv. of $30 \mathrm{mM}, \mathrm{CDCl}_{3}$ ). amine (3-5) in $\mathrm{CDCl}_{3}(30 \mathrm{mM})$ to a solution of racemic 2,3-diphenyl succinic acid 7 . The splitting between methine proton $\left(\mathrm{C}^{\alpha} \mathrm{H}\right)$ signals corresponding to each enantiomer of the acids (6-7) $(\Delta \Delta \delta)$ after addition of receptors (3-5) have been shown in table 3.

For all tested examples, the signals for the protons $\left(\mathrm{C}^{\alpha} \mathrm{H}\right)$ attached to the asymmetric carbon of the substrate were split. In the case of enantiomeric recognition of mandelic acid and 2,3-diphenylsuccinic acid by the macrocyclic amine $\mathbf{3}$ and $\mathbf{5}$, the baseline resolution was good enough for an accurate integration whereas in the case of macrocyclic amine 4 the splitting of the methine proton signal was only 3$4 \mathrm{~Hz}$. The macrocycle 5 was also used to determine the enantiomeric excess of non-racemic samples of 2,3-diphenylsuccinic acid. The difference in chemical shift of the methine proton signals of racemic mandelic acid 6 was found to be $17.6 \mathrm{~Hz}$ in the presence of the macrocyclic amine 3 when the ratio of amine and acid was $1: 3$. However, in the case of 2,3-diphenylsuccinic acid 7, a chemical shift difference of $11.6 \mathrm{~Hz}$ was observed when the ratio of amine and acid was $6: 1$ (figure 6).

To confirm the formation of multimolecular complexes, Job's plot analysis was performed for each enantiomer of acid 6 (figure 3) in separate experiments. A clear 1:3, receptor:acid stoichiometry for both enantiomers of the acid was obseved. These experiments also agree with a tri-protonation state of the macrocycle $\mathbf{3}$ in optimal supramolecular complexes. From the plot (figure 3), it is evident that the chemical shift changes of $(S)$-mandelic acid are greater when compared to the $(R)$-mandelic acid. In order to further assess the discriminating ability of the amine 3 , the titration of the macrocyclic amine 3 with the $(R)$ and $(S)$-mandelic acids was carried out by varying the relative ratio of the amine and acid as $0.25,0.5,0.75,1.00,1.25,1.5,2 \cdot 00,2 \cdot 5$ and 3.00 and the change in chemical shift of the methine signal of the $(R)$ or $(S)$-mandelic acid was recorded. The relative concentration of the amine (C) was plotted against the change in chemical shift of the methine signal $(\Delta \Delta \delta)$ (figure 8).

The splitting of the methine proton signal of the 2,3-diphenylsuccinic acid 7 was found to be good enough $(40 \mathrm{~Hz})$ when the macrocyclic amine 5 was used in $2: 1$ ratio with the diacid 7 . In order to evaluate the efficiency of the amine 5 in the determination of the enantiomeric excess of the diacid 7 , the enantiomeric composition of the non-racemic 


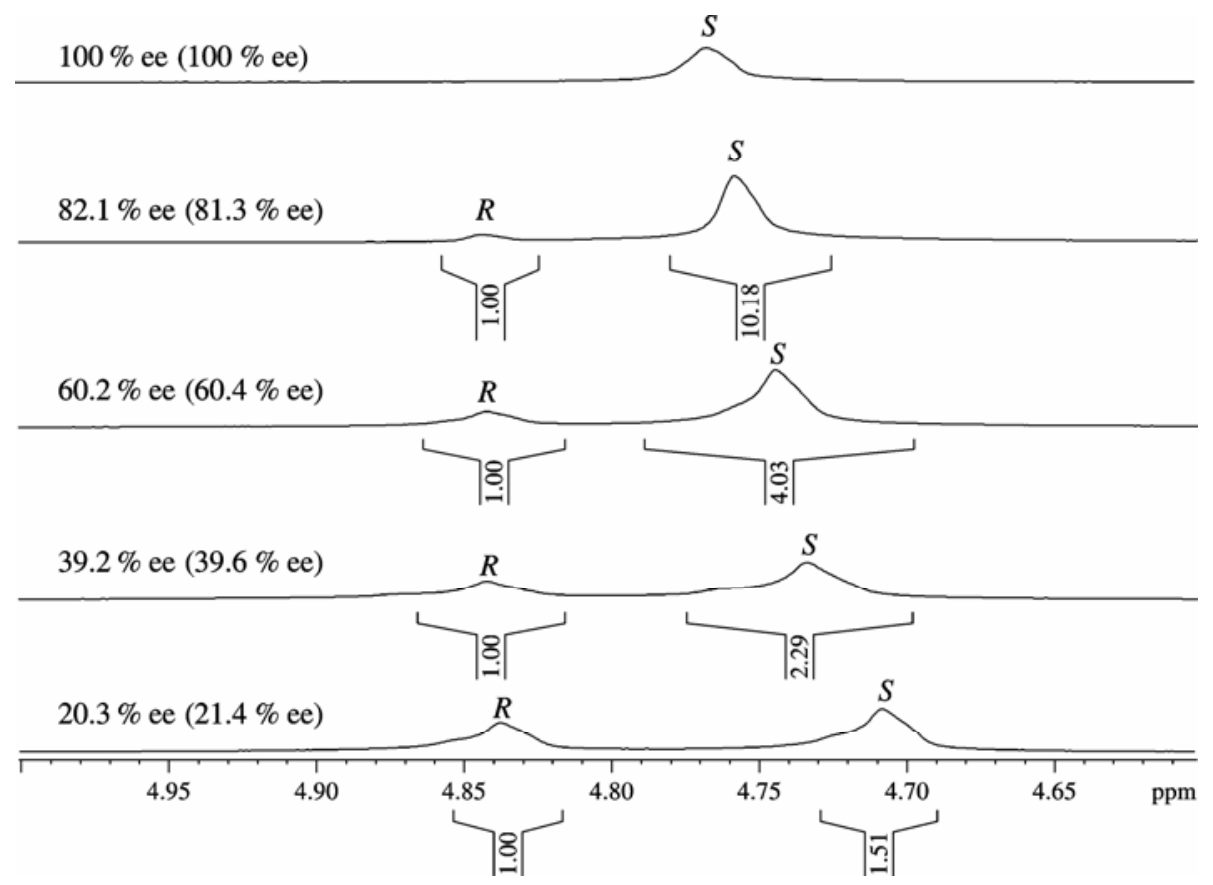

Figure 7. Selected region of the ${ }^{1} \mathrm{H}$ NMR $(400 \mathrm{MHz})$ spectra of $6(100 \mathrm{mM})$ with various enantiomeric purities in the presence of $\left(1 R, 2 R, 1^{\prime} R, 1^{\prime \prime} R\right)-1$ $(100 \mathrm{mM})$ in $\mathrm{CDCl}_{3}$ at $25^{\circ} \mathrm{C}$. The \%ee values were obtained from the integration of the signals and the \%ee values obtained by HPLC analysis are given in parentheses.

Table 3. Measurements of ${ }^{1} \mathrm{H}$ NMR chemical shift non-equivalences $(\Delta \Delta \delta, 400 \mathrm{MHz})$ of methine proton $\left(\mathrm{C}^{\alpha} \mathrm{H}\right)$ signals of the acids 6 and 7 in the presence of the macrocyclic amines 3,4 and 5 in $\mathrm{CDCl}_{3}(30 \mathrm{mM})$ at $25^{\circ} \mathrm{C}$.

\begin{tabular}{|c|c|c|c|c|c|c|c|}
\hline \multirow[b]{3}{*}{ Entry } & \multirow{3}{*}{$\begin{array}{l}\text { Macrocyclic } \\
\text { amine }\end{array}$} & \multicolumn{3}{|c|}{$\hat{\mathrm{O}}_{6}^{\mathrm{OH}} \mathrm{COOH}$} & \multicolumn{3}{|c|}{$\begin{array}{l}\mathrm{Ph} \\
\text { HOOC } \\
7\end{array}$} \\
\hline & & \multirow{2}{*}{$\begin{array}{c}\text { Ratio of } \\
\text { amine : acid }\end{array}$} & \multicolumn{2}{|c|}{$\Delta \Delta \delta$} & \multirow{2}{*}{$\begin{array}{c}\text { Ratio of } \\
\text { amine : acid }\end{array}$} & \multicolumn{2}{|c|}{$\Delta \Delta \delta$} \\
\hline & & & ppm & $\mathrm{Hz}$ & & ppm & $\mathrm{Hz}$ \\
\hline 1 & 3 & $1: 3$ & $0 \cdot 044$ & $17 \cdot 6$ & $6: 1$ & 0.029 & 11.6 \\
\hline 2 & 4 & $1: 6$ & $0 \cdot 011$ & $4 \cdot 4$ & $1: 2$ & 0.009 & $3 \cdot 6$ \\
\hline 3 & 5 & $1: 4$ & 0.034 & $13 \cdot 6$ & $2: 1$ & $0 \cdot 100$ & $40 \cdot 0$ \\
\hline
\end{tabular}

samples of the diacid was determined in the presence of the macrocyclic amine.

The non-racemic samples of the diacid 7 were obtained by partial resolution using $(S)$-proline following a procedure reported from this laboratory to obtain the diacid with $71 \%$ ee from the precipitate fraction and with $17 \%$ ee from the filtrate fraction. ${ }^{26}$ The enantiomeric excess of the non-racemic diacid 7 with $71 \%$ ee and $17 \%$ ee determined by ${ }^{1} \mathrm{H}-\mathrm{NMR}$ in the presence of the amine 5 was in agreement with the ee values measured by optical rotation (figure 9). It was observed that the methine proton signal of the $(S, S)-7$ was shifted more downfield compared to the $(R, R)-7$. In the presence of the macrocyclic amine 4 the splitting of the mandelic acid 6 was $4.4 \mathrm{~Hz}$ and that of 2,3-diphenylsuccinic acid 7 was $3.6 \mathrm{~Hz}$. Optimum results were obtained when the ratio of the macrocyclic amine 3 and mandelic acid was $1: 3$ and that of the amine 3 and 2,3-diphenylsuccinic acid was $6: 1$. In the case of the macrocycle 5 , better 
results were obtained when the ratio of $\mathbf{5}$ and mandelic acid was $1: 4$ and that of 5 and 2,3diphenylsuccinic acid was $2: 1$ (table 3 ).

\section{Conclusion}

Chiral trans-1,2-diaminocyclohexane derivatives 15 were found to be useful as efficient chiral solvating agents (CSA) for the fast and easy determination

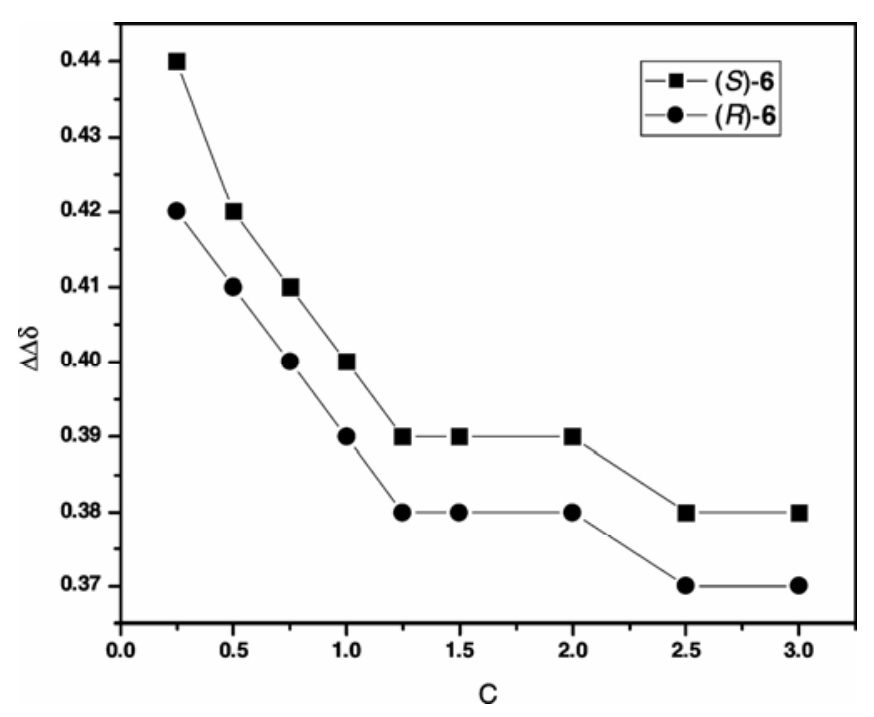

Figure 8. ${ }^{1} \mathrm{H}-\mathrm{NMR}$ titration curves of 3 with $(R)$ - and $(S)$-mandelic acids $6[\mathrm{C}=$ relative concentration of the amine with respect to the acid; $\Delta \Delta \delta=$ change in the chemical shift of the methine proton of 6$]$.

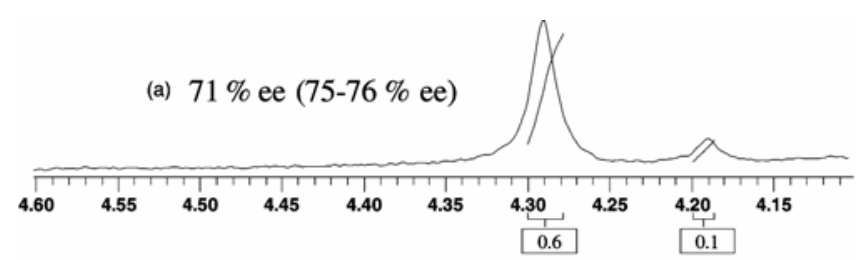

(b) $0 \%$ ee

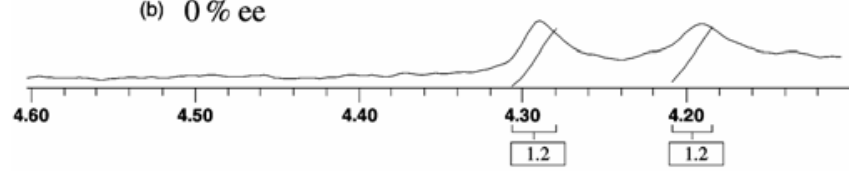

(c) $17 \%$ ee $(19-20 \%$ ee $)$

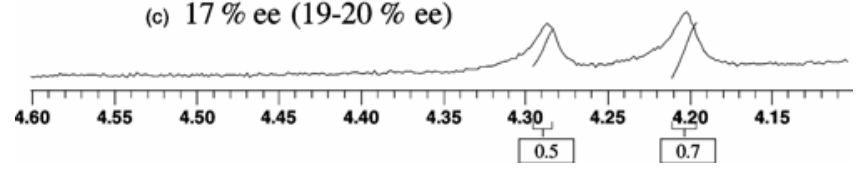

Figure 9. Selected region of the ${ }^{1} \mathrm{H}-\mathrm{NMR}$ spectra of acid $7(0.05 \mathrm{M})$ with various enantiomeric purities in the presence of amine $5(0.05 \mathrm{M})$ with $1: 2$ molar ratio in $\mathrm{CDCl}_{3}$ at $25^{\circ} \mathrm{C}$. The \%ee values given are obtained from integration of the signals and the average \%ee values obtained by graphical analysis of the signals after expansion $(100 \%, 200 \%)$ are given in parentheses. of the enantiomeric purity of carboxylic acids (6-8). The studies indicate that most of these compounds act as polytopic receptors, binding up to three molecules of the substrate. Good splitting of the signals was observed after addition of small amounts of the receptor (CSA). The high symmetry and simple ${ }^{1} \mathrm{H}$ NMR spectrum of these CSA compounds reduce the possibility of large overlapping with signals of the substrate. The formation of diastereomeric complexes is fast and quantitative being possible its in situ analysis by a $400 \mathrm{MHz}$ spectrometer at room temperature. Moreover, as the interaction between receptor and substrate is non-covalent and $\mathrm{pH}$ dependent, both compounds can be separated and recovered by a simple acid-base extraction procedure. The easy accessibility of the chiral receptors (1-5) from commercially available 1,2-diaminocyclohexane should make this methodology very attractive for practical application as chiral solvating agents (CSA) for carboxylic acids.

\section{Acknowledgements}

We thank University Grants Commission (UGC) for support under the University with Potential for Excellence (UPE), Centre for Advanced Study (CAS-SAP) and UGC-MHRD Chemistry Networking Centre programmes. Support of the Department of Science and Technology (DST) under Fund for Improvement of Science and Technology Infrastructure in Universities (FIST) programme and award of the DST-JC Bose National Fellowship grant to MP are gratefully acknowledged. MD is thankful to the Council of Scientific and Industrial Research (CSIR) for research fellowship.

\section{References}

1. Lin J, Hu Q-S, Xu M-H and Pu L $2002 \mathrm{~J}$. Am. Chem. Soc. 1242088

2. Pu L 2004 Chem. Rev. 1041687

3. Lin J, Rajaram A R and Pu L 2004 Tetrahedron 60 11277

4. Valentine Jr D, Johnson K K, Priester W, Sun R C, Toth K and Saucy G 1980 J. Org. Chem. 453698

5. (a) Seco J M, Quiñoá E and Riguera R 2004 Chem. Rev. 104 17; (b) Wenzel T J and Wilcox J D 2003 Chirality 15 256; (c) Parker D 1991 Chem. Rev. 91 1441

6. (a) Uccello-Barretta G, Balzano F, Sicoli G, Scarselli A and Salvadori P 2005 Eur. J. Org. Chem. 5349; (b) Uccello-Barretta G, Balzano F, Martinelli J, Berni M G, Villani C and Gasparrini F 2005 Tetrahedron: Asymmetry 163746 
7. Ema T, Tanida D and Sakai T $2007 \mathrm{~J}$. Am. Chem. Soc. 12910591

8. For recent examples of in situ covalent CSRs, which do not require additional purification steps, see: (a) Pe'rez-Fuertes Y, Kelly A M, Johnson A L, Arimori S, Bull S D and James T D 2006 Org. Lett. 8 609; (b) Chin J, Kim D C, Kim H-J, Panosyan F B and Kim K M 2004 Org. Lett. 62591

9. For example, see: Fraser R R 1983 In Asymmetric synthesis (ed.) J D Morrison (New York: Academic Press) vol. 1

10. (a) Wenzel T J and Thurston J E $2000 \mathrm{~J}$. Org. Chem. 65 1243; (b) Wenzel T J, Thurston J E, Sek D C and Joly J-P 2001 Tetrahedron: Asymmetry 12 1125; (c) Machida Y, Kagawa M and Nishi H 2003 J. Pharm. Biomed. Anal. 30 1929; (d) Lovely A E and Wenzel T J 2006 J. Org. Chem. 719178

11. Wenzel T J, Amonoo E P, Shariff S S and Aniagyei S E 2003 Tetrahedron: Asymmetry 143099

12. (a) Simonato J-P, Chappellet S, Pecaut J, Baret P and Marchon J-C 2001 New. J. Chem. 25 714; (b) ClaeysBruno M, Toronto D, Pecaut J, Bardet M, and Marchon J-C $2001 \mathrm{~J}$. Am. Chem. Soc. 123 11067; (c) Schwenninger R, Schlogl J, Maynollo J, Gruber K, Ochsenbein P, Burgi H-B, Konrat R and Krautler B 2001 Chem. Eur. J. 7 2676; (d) Ema T, Ouchi N, Doi T, Korenaga T and Sakai T 2005 Org. Lett. 73985

13. (a) Webb T H and Wilcox C S 1993 Chem. Soc. Rev. 22 383; (b) Zhang X X, Bradshaw J S and Izatt R M 1997 Chem. Rev. 97 3313; (c) Chen G-M, Brown H C and Ramachandran P V 1999 J .Org. Chem. 64 721; (d) Tejeda A, Oliva A I, Simon L, Grande M, Caballero M C and Moran J R 2000 Tetrahedron Lett. 41 4563; (e) Alfonso I, Rebolledo F and Gotor V 2000 Chem. Eur. J. 6 3331; (f) Tsubaki K, Nuruzzaman M, Kusumoto T, Hayashi N, Bin-Gui W and Fuji K 2001 Org. Lett. 3 4071; (g) Lin J, Hu Q-S, Xu M-H and Pu L 2002 J. Am. Chem. Soc. 124 2088; (h) Kim B M, So S M and Choi H J 2002 Org. Lett. 4 949; (i) Ito K, Noike M, Kita A and Ohda Y 2002 J. Org. Chem. 67 7519; (j) Du C-P, You J-S, Yu X-Q, Liu C L, Lan J-B and Xie R-G 2003 Tetrahedron: Asymmetry 14 3651; (k) Yang X, Wu X, Fang M, Yuan Q and Fu E 2004 Tetrahedron: Asymmetry 15 2491; (1) Ema T, Tanida D and Sakai T 2006 Org. Lett. 83773

14. (a) Pirkle W H and Hoekstra M S $1976 \mathrm{~J}$. Am. Chem. Soc. 98 1832; (b) Pirkle W H and Sikkenga D L 1977 J. Org. Chem. 42 1370; (c) Deshmukh M, Dunach E, Juge S and Kagan H B 1984 Tetrahedron Lett. 25 3467; (d) Toda F, Mori K, Okada J, Node M, Itoh A, Oomine K and Fuji K 1988 Chem. Lett.131; (e) Toda F, Mori K and Sato A 1988 Bull. Chem. Soc. Jpn. 61 4167; (f) Toda F, Toyotaka R and Fukuda H 1990 Tetrahedron: Asymmetry 1 303; (g) Tanaka K, Ootani $\mathrm{M}$ and Toda F 1992 Tetrahedron: Asymmetry 3 709; (h) Bilz A, Stork T and Helmchen G 1997 Tetra- hedron: Asymmetry 8 3999; (i) Lacour L, Vial L and Herse C 2002 Org. Lett. 4 1351; (j) Pakulski Z, Demchuk O M, Kwiatosz R, Osinski P W, Swierczynska W and Pietrusiewicz K M 2003 Tetrahedron: Asymmetry 14 1459; (k) Hebbe V, Londez A, GoujonGinglinger C, Meyer F, Uziel J, Juge S and Lacour J 2003 Tetrahedron Lett. 44 2467; (1) Koscho M E and Pirkle W H 2005 Tetrahedron: Asymmetry 16 3345; (m) Yang D, Li X, Fan Y-F and Zhang D-W $2005 J$. Am. Chem. Soc. 127 7996; (n) Palomino-Schatzlein M, Virgili A, Gil S and Jaime C $2006 \mathrm{~J}$. Org. Chem. 71 8114; (o) Perez-Trujillo M and Virgili A 2006 Tetrahedron: Asymmetry 172842

15. (a) Lin J, Zhang H and Pu L 2002 Org. Lett. 4 3297; (b) Cuevas F, Ballester P and Pericas M A 2005 Org. Lett. 7 5485; (c) Yang D, Li X, Fan Y and Zhang D $2005 \mathrm{~J}$. Am. Chem. Soc. 127 7996; (d) GonzalezAlvarez A, Alfonso I and Gotor V 2006 Tetrahedron Lett. 47 6397; (e) Ma F, Ai L, Shen X and Zhang C 2007 Org. Lett. 9 125; (f) Ema T, Tanida D and Sakai T 2007 J. Am. Chem. Soc. 129 10591; (g) Luo Z, Zhong C, Wu X and Fu E 2008 Terahedron Lett. 49 3385; (h) Pena C, Gonzalez-Sabin J, Alfonso I, Rebolledo F and Gotor V 2008 Tetrahedron 647709

16. Tanaka K, Fukuda N and Fujiwara T 2007 Tetrahedron: Asymmetry 182657

17. Tanaka K and Fukuda N 2009 Tetrahedron: Asymmetry 20111

18. Zhang X-X, Bradshaw J S and Izatt R M 1997 Chem. Rev. 973313

19. Padmaja M and Periasamy M 2004 Tetrahedron: Asymmetry 152437

20. Dalai M and Periasamy M 2009 Tetrahedron: Asymmetry 201247

21. Gawronski J, Kolbon H, Kwit M and Katrusiak A $2000 \mathrm{~J}$. Org. Chem. 655768

22. Pine S H and Sanchez B L $1971 \mathrm{~J}$. Org. Chem. 36 829

23. Prasad A S B, Kanth J V B and Periasamy M 1992 Tetrahedron $\mathbf{4 8} 4623$

24. For the synthesis of a similar type of $C_{2}$-symmetric tetraazamacrocycle containing 1,2-diaminocyclohexane moiety with aliphatic spacers see Alfonso I, Astorga C, Rebolledo F and Gotor V 1999 Tetrahedron: Asymmetry 102515

25. González-Älvarez A, Alfonso I, Díaz P, GarcíaEspaña E and Gotor V 2006 Chem. Commun. 1227

26. Ramanathan C R and Periasamy M 1998 Tetrahedron: Asymmetry 92651

27. Larrow J F, Jacobsen E N, Gao Y, Hong Y, Nie X and Zepp C M 1994. J. Org. Chem. 591939

28. Matsumura $Y$, Nishimura M, Hiu H, Watanabe $M$ and Kise N 1996 J. Org. Chem. 612809

29. Ebbers E J, Ariaans G J A, Bruggink A and Zwanenburg B 1999 Tetrahedron: Asymmetry 10 3701 